JOURNAL OF SECURITY AND SUSTAINABILITY ISSUES

ISSN 2029-7017 print/ISSN 2029-7025 online

2019 September Volume 9 Number 1

http://doi.org/10.9770/jssi.2019.9.1(6)

\title{
Scopus
}

\section{BEHAVIORAL MODELS FOR ENSURING THE SECURITY OF FUNCTIONING AND ORGANIZATIONAL SUSTAINABILITY OF THE ENTERPRISE}

\author{
Nataliia Savytska $^{1}$, Hanna Chmil' ${ }^{2}$, Olena Hrabylnikova ${ }^{3}$, Olena Pushkina ${ }^{4}$, Maria Vakulich \\ ${ }^{1,2 *}$ Kharkiv State University of Food Technology and Trade, Klochkivska Square, 333, Kharkiv, 61051, Ukraine; \\ ${ }^{3}$ Oles Honchar Dnipro National University, 35, Yavornitskogo str., Dnipro, 49000, Ukraine; \\ ${ }^{4,5}$ Alfred Nobel University, Naberezhna Sicheslavska str., 18, 49000, Dnipro, Ukraine \\ E-mail: ${ }^{2}$ koaduep@gmail.com
}

Received 15 October 2019; accepted 8 June 2019; published 30 September 2019

\begin{abstract}
In the scientific work, the factors of perception of management styles have been studied in order to ensure the security of functioning of the enterprise in the context of the transformation of the social system when implementing strategies aimed at its development. The paradigm of decision making on interference in functional processes has been studied for ensuring the security and organizational sustainability of the enterprise. The main components of the formation of corporate models of sustainability and security of enterprise development have been considered and classified.
\end{abstract}

Keywords: ensuring security, organizational sustainability of the enterprise, behavioral model, management styles, staff of the enterprise, adjustment effects, society

Reference to this paper should be made as follows: Savytska, N.; Chmil, H.; Hrabylnikova, O.; Pushkina, O.; Vakulich, M. 2019. Behavioral models for ensuring the security of functioning and organizational sustainability of the enterprise, Journal of Security and Sustainability Issues 9(1): 63-76. http://doi.org/10.9770/jssi.2019.9.1(6)

JEL Classifications: F52, O39

\section{Introduction}

The management style and behavioral processes are one of the effective factors of influence on the overall efficiency of the management functions, that is, they are an influential factor in ensuring the overall efficiency of the enterprise. In today's conditions, when on the basis of using information technologies and perfect telecommunication equipment, a significant progress has been made in the implementation of management as a continuous cyclical process, the most significant reserves of efficiency increase are associated with the behavioral features for ensuring the security of functioning and organizational sustainability of the enterprise, which together form a specific style of managerial influence. That is why a large number of studies have been devoted to the problem of adaptation and improvement of management styles in order to maintain the security of the enterprise. In particular, there are systems' studies of Bartol, Tein et. al. 2003; Bushe, et. al. 2009; Cao, and McHugh, 2005; Srivastva, and Cooperrider, 1999; Worley, et. al. 1996; Zucker, 1987; Bombiak, 2019; Koval et. al., 2019; Ključnikov et al., 2019; Hasanudin et al., 2019.

At the same time, there is a lack of detailed consideration of issues both relating to the management style with the limits of perception and demand for the safe and even growth of the enterprise in these studies. Indeed, the management style (strictly speaking, the unity of the management style within a particular enterprise is meant) makes directly an influence on the psychological climate of the enterprise, the employee engagement level of the enterprise in the implementation of tactical and strategic goals and objectives. Therefore, the enterprise 
should formulate forward-looking plans for improving the management style, adapting to strategic tasks, ensuring unity of style at the enterprise, transforming the management style into an important element of organizational security of the enterprise (Monni et al., 2017).

The purpose of scientific work is both determination and organizational interaction of using behavioral models for ensuring the security of functioning and organizational sustainability of the enterprise.

\section{Literature Survey}

It is clear that the management style, which characterizes the behavioral features of one of the staff groups (human resources), belongs to the internal variables of the enterprise that are under the control of the management. However, the behavioral features of people are a function of the individual, the formation process of which is determined by the dynamics of social structure, the typology of social characters and the orientation to different groups of values. Moreover, the perception of a certain management style and the orientation (expectation) of a separate type of management by the enterprise staff are also determined by the eastern set of external sociopolitical factors. Thus, the transformation of the behavioral features of people is the most effective factor that makes an influence on the attraction to certain behavioral profiles and both open and hidden attitude to the behavioral features of the management functions Zeman, et. al. (2018).

Thus, external factors not only affect, but also directly determine certain parameters of such an important internal variable as different elements of the staff structure of the enterprise and the relationship between employees (Drobyazko S., 2017). The latter circumstance is very important in the sense that the task of working out this influence at the enterprise level is very complicated due to the need to take into account the complex effects of mutual adjustment of various elements of the staff structure. Such elements may lead to internal contradictions and, as a consequence, to additional barriers to the way of implementing the enterprise strategy. At the same time, the possibility of controlling these variables from the enterprise is very limited, that is, even if there is a moderate promising policy of the enterprise regarding the development of individual structural elements of the staff, the possibility of ensuring positive changes in the efficiency of activities is not guaranteed (Zhou, et. al. 2017).

\section{Methods}

The latter provision necessitates a detailed study of the effects of perceptions of management styles in order to ensure the security of functioning of the enterprise in the context of the transformation of the social system against the background of implementing the strategy aimed at its development, ensuring its competitiveness in the globalized world economy.

From these considerations, the tasks of this study are:

determination of value systems, towards which the typology of managers and employees of the enterprise is separately directed;

identification of the transformation effects of public values both in the behavior of managers and the attitude of enterprise staff to the behavioral features of the management functions;

formation of perspective recommendations on adaptation and development of management styles and adaptation to the development process of the motivational structure of the enterprise staff at the stage of entering the world economic system.

In order to solve the first problem, it is necessary to determine the features of the transformation of the public value system, on which the staff and management of the enterprise are oriented. As a rule, in societies that exist under stable conditions, the values to which the staff and management of the enterprise are oriented coincide. However, with respect to societies in a state of transformation of the social system, one can put forward the hypothesis that the permissible values differ in that the process the reorientation to a new value system for management is more rapid than for the enterprise staff. 


\section{Results}

The issue of ensuring organizational stability and security of development in a competitive struggle and determining the moment of reorganization of activities in order to ensure competitiveness are vital for the achievement of a dynamic enterprise development. Both of these directions directly relate to the release of the effect of non-material factors of ensuring competitiveness (Drobyazko S., 2019).

Accumulation of the mismatch of the current organizational state of the enterprise, namely, its set of internal and external variables is an objective process that can be completed through a series of crisis stages of development, when the competitiveness of the enterprise suddenly decreases not only due to the influence of external but also internal factors. A controlled change in organizational status makes it possible to minimize the negative impact (and if possible, exclude such an impact).

The behavior of the enterprise and security are determined by the subject of its management, while the choice of the development path under conditions of chaos, according to (Mathis, 2011), is purely random:

"At this turning point (which is called the bifurcation point) it is fundamentally impossible to predict in what direction further development will take place; whether the state of the system becomes chaotic or it moves to a new, more differentiated and higher level of ordering." This distinction gives the subject of management the opportunity to use the interpretation of the unstable state of the enterprise as a tool for choosing the right solution that does not allow the disintegration of the system.

The second difference is the capability of the organization to overcome serious deviations, asymmetry of reactions, organizational hysterezis, leaving the enterprise at the same time in a state of functioning.

For the enterprise it is a rather slow transition from the unstable state at the bifurcation point to the equilibrium state of the transformed system or, conversely, to the state of the organizational crisis. External influences on the activity of the enterprise may lead to a temporary change in its organizational parameters, however, after their termination, the organization may well return to its former state. At the same time, we observe that because of the influence of various factors, the organization moved from one state to another.

Let us give examples:

- once a unitary enterprise has become corporate one;

- the former workshop has become a separate enterprise;

- the operation of a certain technological equipment has ceased;

- the previously existing technological specialization of the site has changed to the subject;

- directions of traffic flow have changed;

- the need for workers of a certain profession and qualification has disappeared, etc.

The capability of ensuring the organizational sustainability of enterprises largely depends on timely knowledge of future critical points, namely, of bifurcations. Researchers note the features of the behavior of the system, according to which this critical point approaches (Cummins, and Worley, 2005; Makedon, et. al. 2019a). These are:

- the presence of several different (stable and unstable) states, of which the system is displayed by weak "shocks";

- irreversibility (impossibility to return to the previous conditions);

- the presence of a delay in the reaction to changes in the system, which manifests itself in the phenomena of organizational hysteresis, etc.

Thus, the organizational stability of the enterprise's activity should be understood as its capability to adjust or change its organizational state in order to counteract the end of the organizational crisis and ensure its functioning. Accordingly, the measure of organizational sustainability should be measured by the size of resources at the disposal of enterprises that are able to move the onset of an organizational crisis for a certain period, or not to allow it at all through using resources for the reorganization of activities at the time of the bifurcation point. 
The activity of the enterprise takes place in market conditions, the rate of change of which becomes almost unpredictable, and why the suddenness with which the global economic crisis has captured most countries, industries and individual enterprises has become a misconception. In these conditions, all functions of modern management are filled up with a new content, including the need for its implementation in the form of organizational behavior of the enterprise in relation to the organization's function, the main task of which is to provide a certain level of organizational sustainability (Kubeš, and Rančák, 2018).

Unfortunately, the negative experience of many enterprises in the process of growing crisis and attempts to overcome it shows that they lack not only the capability to find the necessary solutions, but also the presence of the system of activities aimed at ensuring the stability of the enterprise in changing conditions. The requirement to ensure organizational sustainability formulates the following paradigm for decision-making on interference with an operating organization (Table 1).

Gray background with an increase in its depth in the table 3.6 refers to the inactive relation of the subject of management to the accumulation of negative consequences of the influence of environmental variability on the organization of activity, which inevitably leads to an organizational crisis.

On the contrary, in the case of decision-making on the reorganization of activity according to the changed environmental conditions, it is necessary (Jankelová, et. al. 2018; Mason, 2007):

1) to monitor the external environment and the position of the enterprise in the part of the change of organizational relations 11 with other elements of the environment, which is crucial for the continuation of functioning of the enterprise. In the case of detecting a certain direction of the volatility of the environment, it is necessary to select its concentrated parameter and establish the point of beginning of volatility;

Table 1. The paradigm for decision-making on interference with functional processes in order to ensure the security and organizational sustainability of the enterprise

\begin{tabular}{|c|c|c|c|c|}
\hline № & 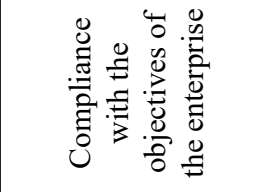 & 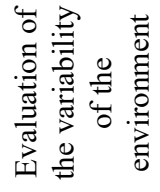 & $\begin{array}{l}\text { Consequences of the influence of the } \\
\text { external environment variability on the } \\
\text { state of the organization }\end{array}$ & $\begin{array}{l}\text { Decision-making on } \\
\text { reforming activities }\end{array}$ \\
\hline 1 & 2 & 3 & 4 & 5 \\
\hline 1 & Corresponds & \multirow{2}{*}{ 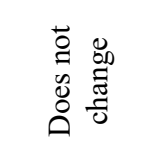 } & Consequences are absent & Interference is not required \\
\hline 2 & $\begin{array}{l}\text { Does not } \\
\text { correspond }\end{array}$ & & $\begin{array}{l}\text { Relative deviations of the operating } \\
\text { organization from due relevance }\end{array}$ & $\begin{array}{l}\text { Adaptive interference in order to restore the } \\
\text { required level of relevance }\end{array}$ \\
\hline 3 & \multirow{4}{*}{$\begin{array}{c}\text { Corresponds or } \\
\text { does not correspond }\end{array}$} & \multirow{4}{*}{ 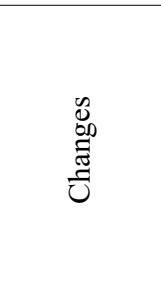 } & \multirow{2}{*}{$\begin{array}{l}\text { Increasing organizational instability } \\
\text { before the bifurcation point }\end{array}$} & $\begin{array}{l}\text { Systematically economically feasible } \\
\text { correction of the organization }\end{array}$ \\
\hline 4 & & & & $\begin{array}{l}\text { Expecting a bifurcation point in order to } \\
\text { make a final decision }\end{array}$ \\
\hline 5 & & & \multirow{2}{*}{$\begin{array}{l}\text { The onset of the organizational } \\
\text { bifurcation point }\end{array}$} & Decision-making on reorganization \\
\hline 6 & & & & $\begin{array}{l}\text { Pass the bifurcation point in anticipation } \\
\text { of an organizational crisis }\end{array}$ \\
\hline 7 & \multirow{2}{*}{$\begin{array}{l}\text { Corresponds or } \\
\text { does not correspond }\end{array}$} & \multirow{2}{*}{$\begin{array}{l}\mathscr{D}_{0} \\
\text { 焉 } \\
\text { 己 }\end{array}$} & \multirow{2}{*}{$\begin{array}{l}\text { Further variability outside the } \\
\text { bifurcation point }\end{array}$} & $\begin{array}{l}\text { Decision-making on reorganization with } \\
\text { using additional resources in order to } \\
\text { overcome a possible crisis }\end{array}$ \\
\hline 8 & & & & $\begin{array}{l}\text { Expectation of further decisions on the } \\
\text { elimination of the enterprise from the } \\
\text { state of the organizational crisis }\end{array}$ \\
\hline
\end{tabular}

Source: Hamel, and Zanini, 2014; Marshak, and Grant, 2008.

2) to measure variables of the environment and enterprise activity;

3) to evaluate of the level of organizational sustainability of the enterprise, admission to further change of pa- 
rameters, as well as the establishment of the bifurcation point, that is, the extreme state of return indicators, the further deterioration of which makes it impossible to prevent the state of the organizational crisis;

4) to implement the measures in order to support the organizational sustainability of the enterprise at a certain level;

5) to evaluate the onset of the organizational bifurcation point.

One of the most complex things, both theoretical and practical, is the question of choosing the moment of the necessary transition from the active form to the new one, that is, the timely recognition of the future critical bits of bifurcation. The capability of ensuring organizational sustainability of enterprises directly depends on it (Aghina, et. al. (2014).

According to the determination of the point of organizational bifurcation, an unlimited level of organizational sustainability of the enterprise can accumulate, but the very moment of the onset of the bifurcation point depends on the expected onset of an organizational crisis.

The development of a market economy, even with elements of state capitalism in strategically important areas of activity, leads to an increase in the influence of corporations on society. Essential assistance in implementing such a process could be provided by specially developed models of corporate behavior (Načisčionis, et. al. 2018). These models do not need to be invented; they exist in the real practice of companies, they only need to be highlighted and described as sustainable socio-psychological features of the behavior of companies and their constituent individuals.

Let us consider two main components of corporate sustainability and security models for the enterprise: social responsibility and education index. Using them as variables, we can plot the compliance matrix presented in Fig. 1. It makes it possible to distinguish five main models of corporate behavior. Theoretically, the alternatives are possible, but the below models are more common.

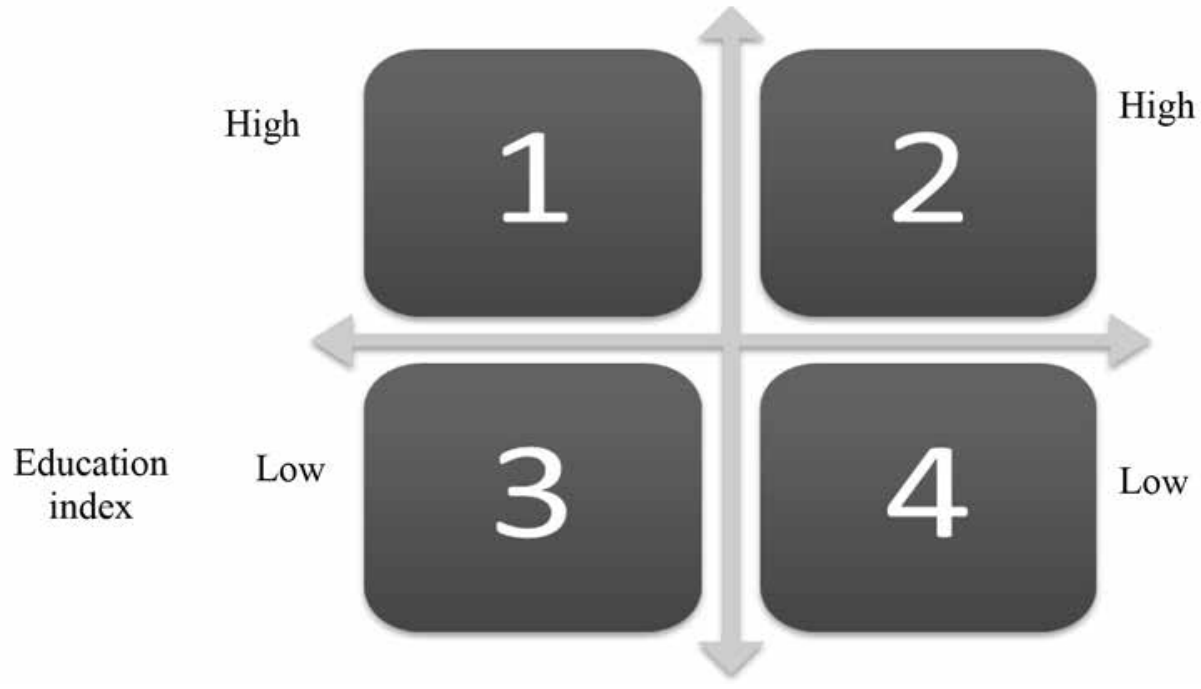

Fig.1. Compliance matrix of forming corporate models of sustainability and security

Source: Cameron, and Quinn, 2011; Limba, and Šidlauskas, 2018

1. The model of "intensive promotion" represents such behavior of the enterprise, which manifests itself in attracting to its activities the most accessible number of emerging opportunities. At the same time, both different external areas of activity and internal characteristics of the enterprise are included among the opportunities. External circumstances include the possibility of diversification, concentration on certain segments up to the monopolization of the market niche, different types of strategies for vertical integration. Internal circumstances consist in using the smallest opportunities for internal development of the company, including training and 
other types of personnel development (Korauš, \& Kelemen 2018). The result of such an organization's management behavior is "concentrated development", which can be represented by the diagram presented in Fig. 2

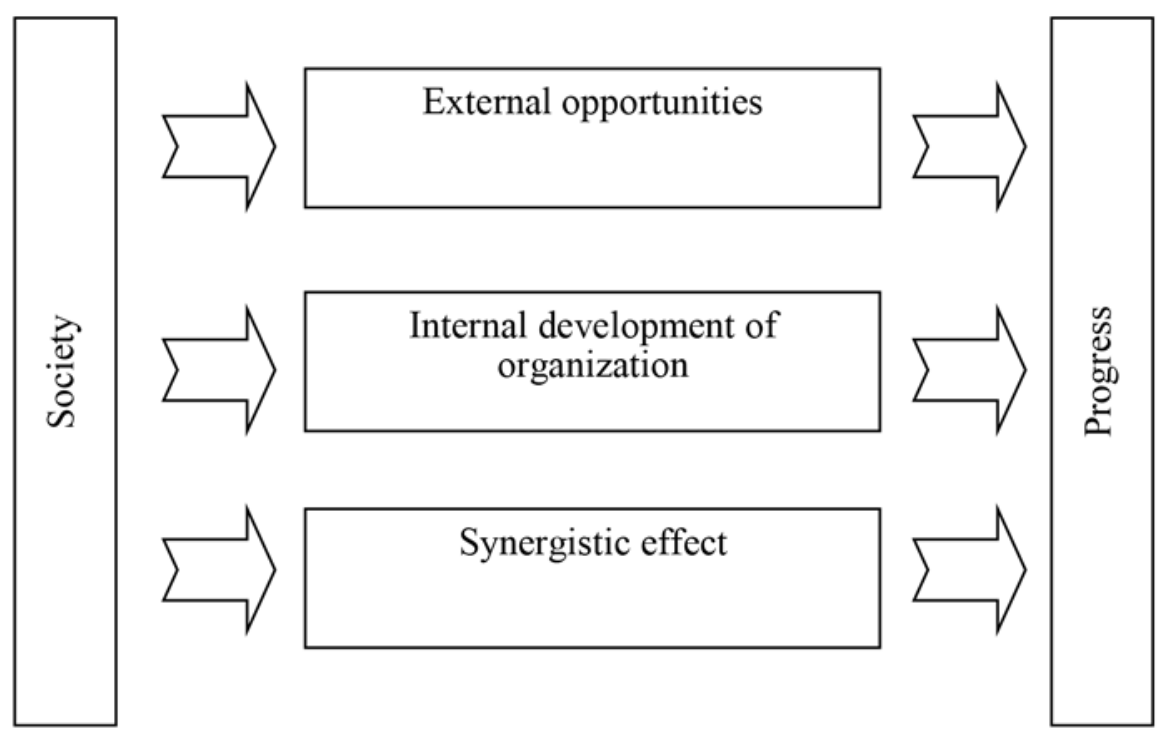

Fig. 2. Diagram of organization's "concentrated development"

Source: Designed by the authors

The influence of such a behavioral model on the society can be described through an analysis of the organization's influence on the development of society. Indicator at the initial stage of development can be the return magnitude on each member of society. This indicator differs from the usual return characteristics for each employee. The return on each member of the society can be represented as a derivative (converted from the ratio of infinitesimal values): $d P / d F$, where $P$ is the level of total return (in fact, GDP), and $F$ is the number of members of society. The derivative $d P / d F$ is the average return value of the population of society, including through the creation of a creative, positive atmosphere in society (Page, et. al. 2012).

It manifests itself in three aspects of the activities of each organization. The first of these, "external opportunities", can be described by linear dependence on time, because for a developing company, over time, their accumulation is taking place.

As an example, let us consider one of the manufacturing companies, which, having started work more than ten years ago from one plant, is today a holding company with eleven lines. The dependence has the form of $k_{1} \sqrt{t}$, where $k_{l}$ is the dimensional coefficient, $t$ is the current time. For the example given, $k_{1}=0,917$. The second aspect of activity, "internal development", is associated with many factors. One of the most significant, explicit and easily controlled aspects is the training of staff, and especially of managers. Here, the linear dependence on time with form of $k_{2} \sqrt{t}$ is also the most reasonable, where $k_{2}$ is the dimensional coefficient, $t$ is the current time. In our example, $k_{2}=0.6$. Synergistic effects can be represented by a stronger dependence, which should include both listed dependences, and at least one degree of dependence on time $t$ should be added. Then the real dependence will have the form of $k_{3} t \sqrt{t}$. However, there is a complexity with the determination of the magnitude of $k_{3}$ in the considered example; it has become possible to control the progress of leading specialists of one of the key departments of the enterprise at a controlled time, which resulted in an estimate equal to 0.2 (Smith, et. al. 2014). The parallel effect of these aspects of the organization's work can be taken into account by summing up their inverse values, and the equation describing the behavior of the organization will look like:

$$
\frac{d P}{d F}=A k_{1} k_{2} k_{3} t \sqrt{t}\left[k_{3} t+\left(k_{1}+k_{2}\right)\right]
$$


After integration, one obtains:

$$
P_{t}=0.286 g A k_{1} k_{2} k_{3}^{2}\left(t^{2} \sqrt{t}+1\right)+0.25 g A k_{1} k_{2} k_{3}\left(k_{1}+k_{2}\right)(t \sqrt{t}+1)
$$

where $g$ is a dimensional proportionality factor;

$t$ is the current time.

From the expression (2), we can see that this behavior of the enterprise, which includes corporate or joint training, makes most likely a growing contribution to the development of society. From this, it follows that the training and (or) advertising and marketing activities, the development of strategies should be focused on the formation of the latter from the considered models of company behavior.

2. The model of "cautious sensing" represents such a form of behavior of the enterprise, which is implemented in case of careful thought and clarification of all aspects of the decision. Schematically, the activity of such an organization is shown in Fig. 3.

1) to measure variables of the environment and enterprise activity;

2) to evaluate of the level of organizational sustainability of the enterprise, admission to further change of parameters, as well as the establishment of the bifurcation point, that is, the extreme state of return indicators, the further deterioration of which makes it impossible to prevent the state of the organizational crisis;

3 ) to implement the measures in order to support the organizational sustainability of the enterprise at a certain level;

4) to evaluate the onset of the organizational bifurcation point.

$$
\frac{d V}{d F}=\eta \frac{d P}{d F}+Z
$$

In order to move to the time variable $t$, it is necessary to consider that members of society participate in its activities, investing in working time, and therefore the contribution of people ultimately determined by how much time these people have invested in the work for the benefit of society. Then we can write that $F=g t$, where $g$ is still a dimensional coefficient of proportionality, and $t$ is the current time.

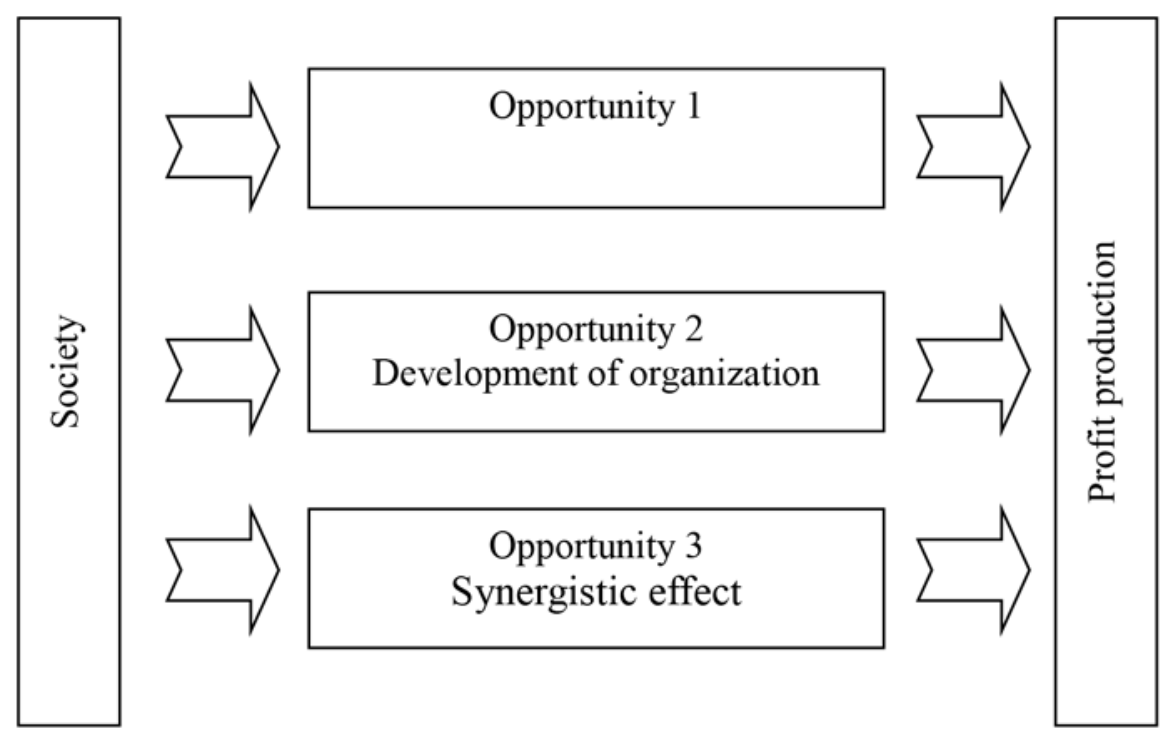

Fig. 3. Scheme of organization's functioning on the model of "cautious sensing" 
After integrating and transforming in the light of the last circumstance:

$$
P_{2}=\frac{V \xi}{\eta}-\frac{Z g t}{\eta}
$$

Thus, despite all the caution of the organization, the positive effects of its activities for society over time are reduced. Probably the reason for this is quite a lot, but most likely, one of the most obvious and significant reasons may be the lack of developmental concerns.

3. Unfortunately, the model of "blind enrichment" is still widespread. Its feature is that the organization uses any provided opportunities not for development but for enrichment, therefore the activity of such an organization harms the society (Fig. 4).

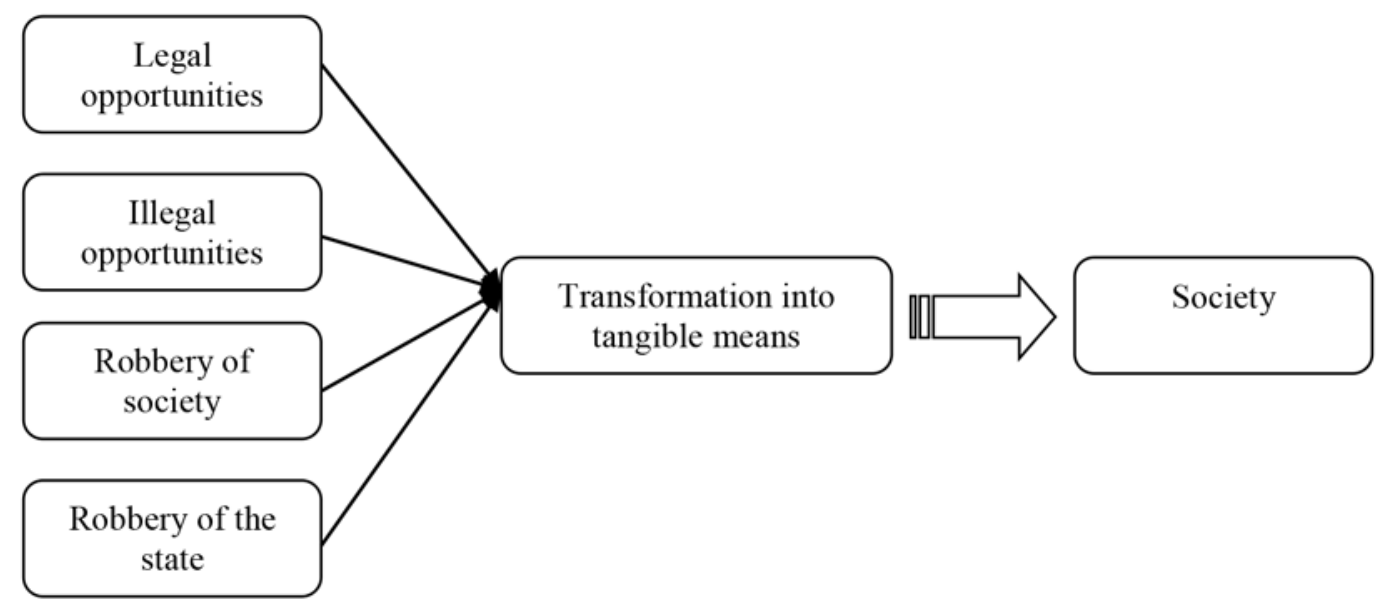

Fig.4. Scheme for implementation of the model of "blind enrichment"

Source: Designed by the authors

The behavior of the enterprise in this case is described by a negative production function. Then the specific return is equal to the negative production function. If we adopt the approach of Cobb-Douglas production function known from the literature (Matthews, 2015), it is necessary to introduce the normalization factors $\omega$ (which is the degree of processing of input resources) and $\chi$, which reflects the use of human resources. Then:

$$
\frac{d P}{d F}=-\frac{d W}{d F}=-\omega \chi \exp (0.0294 t) G^{0.397} L^{0.768}
$$

The boundary condition can be considered $\left.P\right|_{t=0}=0$, because, of course, those who follow this model begin with a certain estimate of $N$, trying to "get out into people". Based on this:

$$
P_{3}=N-\omega \chi \exp (0.0294 t) G^{0.397} L^{0.768}
$$

From formula (6), we can see that the contribution of such an organization, even if neglected by influence on other indicators, falls. There are no driving forces that could push such an enterprise to civilized activities, within which programs for the development of personnel with inevitable elements of training could be considered.

4. The "resource-based" model. The essence of enterprise behavior by such a model is simple and understandable. Having access to resources, the organization converts them to demand for material income, profit, etc., affecting society in two ways (Fig.5). 


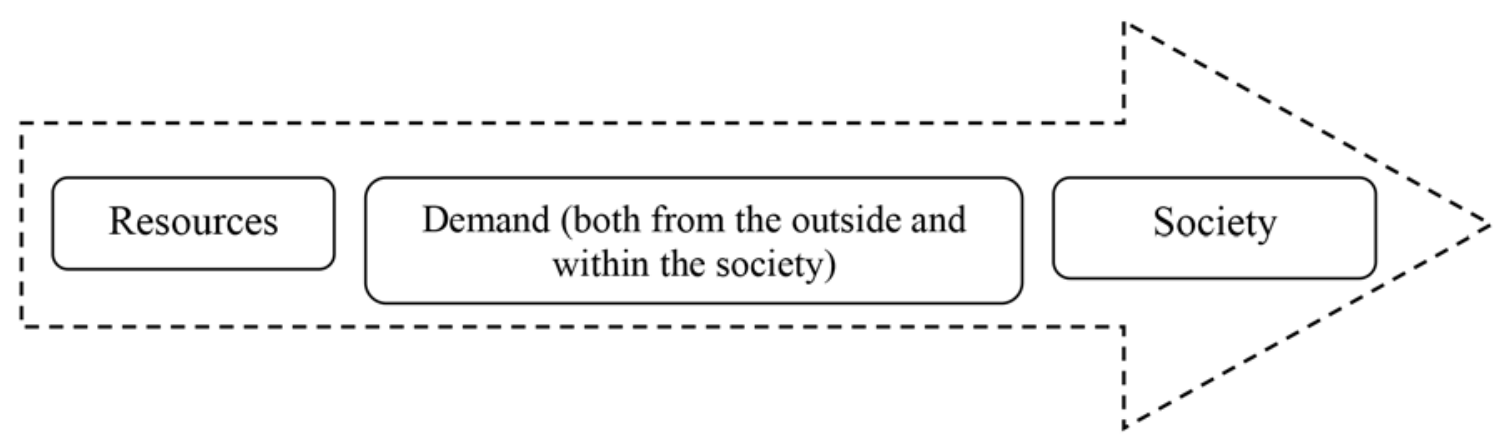

Fig. 5. Scheme for implementation of "resource-based" model

Source: Designed by the authors

The first of them manifests itself through taxes, rent payments, the second one manifests itself through using extracted resources in society, which increases the turnover of the economy and, accordingly, leads to an increase in national wealth. However, if the first way of influencing has some delay in influencing the society within the fiscal year, the delay of the second may be very large, and in some cases, infinitely large and never realized (Korsakiené, et. al. 2017).

Resources have an unpleasant feature. They have a habit of exhaustion, and if their disappearance "to the last drop" does not occur, then the availability of resources becomes more difficult, and the costs of their receipt are growing rapidly. This position can be described by the exponential exp(-mt), where $m$ is the dimensional coefficient. On the other hand, the demand is described by the well-known S-shaped curve and the degree indicator in the expression for it is better to choose equal to 2 . Then the expression for demand $1-\exp \left(-t^{2} / b\right)$ will make it possible using the dimensional coefficients $a_{1}$ and $a_{2}$ to obtain the value of the possible material flow $M=a_{1}$ $\left[1-\exp \left(-t^{2} / b\right)\right]-a_{2} \exp (-m t)$. The tax influence on society is determined as a function of the material flow by the expression $\gamma M \exp \left[m_{1}(t-\tau)\right]$. In this expression, $\gamma$ represents the effective value of the "tax burden", $\tau$ is the level of late payment of taxes, and the entire exponent reflects the latency calculation. Adding due to the influence of the processing of resources on society will look like $\lambda\left[1-\exp \left(-t^{2} / b\right)\right] \exp \left[m_{1}(t-\theta)\right]$. Here $\lambda$ is the share of the influence on society of these processes, $\theta$, as before, is the delay level of the indicated influence. Then we can get the equation:

$$
\begin{aligned}
\frac{d P}{d F} & =-\gamma \exp \left[m_{1}(t-\tau)\right]\left\{a_{1}\left[1-\exp \left(\frac{t^{2}}{b}\right)\right]-a_{2} \exp (-m t)\right\}+ \\
& +\lambda\left[1-2 \exp \left(\frac{t^{2}}{b}\right)\right] \exp \left[m_{2}(t-\theta)\right]
\end{aligned}
$$

After integration, one obtains:

$$
\begin{aligned}
& P_{4}=-g \frac{\gamma a_{1}}{m_{1}} \exp \tau \exp \left(m_{1} t\right)-2 g \frac{\gamma a_{1}}{m_{1}} \exp \tau \exp b \exp \left(m_{1} t\right) \exp \left(\frac{t^{2}}{b}\right)- \\
& -\frac{\gamma a_{1}}{m_{1}} \exp \tau \exp \left[\left(m_{1}+m_{2}\right) t\right]+g \frac{\lambda}{m_{2}} \exp \left[m_{2}(t-\tau)\right]+ \\
& \quad+2 g \frac{\gamma}{b m_{2}} \exp \left[m_{2}(t-\tau)\right] \exp \left(\frac{t^{2}}{b}\right)-g \exp \left(\frac{t^{2}}{b}\right) \times \\
& \quad \times\left\{2 g \frac{\gamma a_{1}}{m_{1}} \exp \tau \exp b \exp \left(m_{1} t\right)+\frac{\gamma}{b m_{2}} \exp \left[m_{2}(t-\tau)\right]\right\}
\end{aligned}
$$

From expression (8), it is clear that after the integration, the general nature of the dependence will not change and the contribution to the development of society appears as a function of the depletion of the source. 
5. The model of "standard functioning". This model is a reflection of the usual practice in human society. The company converts resources and opportunities, and then they are put at the disposal of the society (David, $\&$ David, 2016). Derivative $d P / d F$ in this case is a function of the degree of processing and (or) processing of input resources and opportunities (Fig.6).

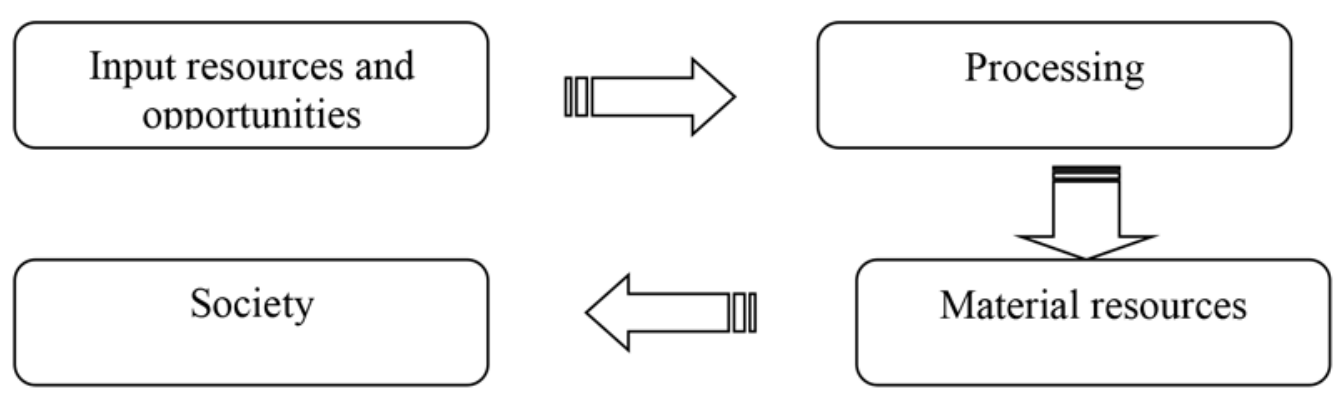

Fig.6. Scheme for implementation of the model of "standard functioning"

Source: Designed by the authors

A special case of this dependence is a linear dependence, then $d P / d F=\omega S_{\text {input }} / M_{\text {output }}$. This ratio is a production function adopted in the economy. One of the most demonstrative production functions, as already noted, is the Cobb-Douglas function: $W=1,038 e^{0,0294 t} G^{0,397} L^{0,768}$, where $G$ is the amount of fixed capital used; $L$ is the cost of living labor.

Then:

$$
\frac{d P}{d F}=\omega \exp (0.0294 t) G^{0.397} L^{0.768}
$$

In addition, one has to introduce the coefficient $g$, representing the return on the company's own promotional activities, rather than inheriting. This means that in fact this coefficient reflects the level of attention to development, mainly to study. The model shows a slight increase in the influence of the organization, but it is rather weak and also demonstrates the importance of learning in order to increase the organization's contribution to the development of society.

$$
P_{5}=34 g \omega \exp (0.0294 t) G^{0.397} L^{0.768}
$$

The comparison of models of corporate behavior should be conducted under the same conditions. For this purpose, constant coefficients have been determined for a group of organizations of a close profile (Fig. 7). The coefficients for the studied case are: $V=0,2 ; \xi=1 ; \eta=0,2 ; Z=0,1 ; g=0,1 ; \gamma=0,05 ; m=0,1 ; m_{1}=0,1 ; m_{2}=0,1 ; a_{1}=0,1$; $b=0,5 ; a_{2}=0,1 ; \lambda=0,12 ; \tau=0,2 ; \theta=0,1 ; \omega=0,1 ; A=1 ; N=0,14 ; G=0,2 ; L=0,2$.

The obtained result is presented in Fig. 7, from which it is clear that the models of "cautious sensing" and "blind enrichment" show a steady decline (the first model is probably due to the weak use of all opportunities, the second one is due to the exhaustion of these opportunities at the expense of "predatory" exploitation). "Resourcebased" model initially gives a rapid growth, and then the same rapid drop, and in the interval of time, which approximately corresponds to 0,35 of all the interval described.

\section{Discussion}

The reason is probably that originally this organization is gaining market of raw materials and there is a constant increase in opportunities. Then it turns out that the organization achieved much more at first level, and then it cannot further give other interesting offers, so that interest in it falls. Moreover, the further is the process of extraction of minerals, the more "deaf", hard-to-reach, dear arrays of these fossils have to be mastered; the profitability of the company is falling, and with a lack of resources, the returns are reduced. A stable, but small increase is given by the model of "standard functioning", which, obviously, is a reflection of an established 
system of interaction with suppliers and consumers, as well as with society as a whole. The fastest growth is given by the option of "intensive promotion", probably with reaching the plateau outside the reporting period, that is, beyond the limits of this model.

The correlation of the return rates in Fig.7 shows that such a diagram is appropriate for choosing the organization's development strategy, correlating the real opportunities with those estimates of development trends that can be made on the basis of data. However, the extremes are implemented rarely in development, and managers can use both parallel and consistent application of the above models (Kabát, et. al. 2017). In this case, the strategy of the organization's development will represent a pre-selected combination of the above-mentioned variants of the behavior of the enterprise, which makes it possible to formalize the process of strategic management of the organization and, accordingly, to facilitate strategic planning and to reduce the likelihood of strategic mistakes that are very dangerous for the organization.

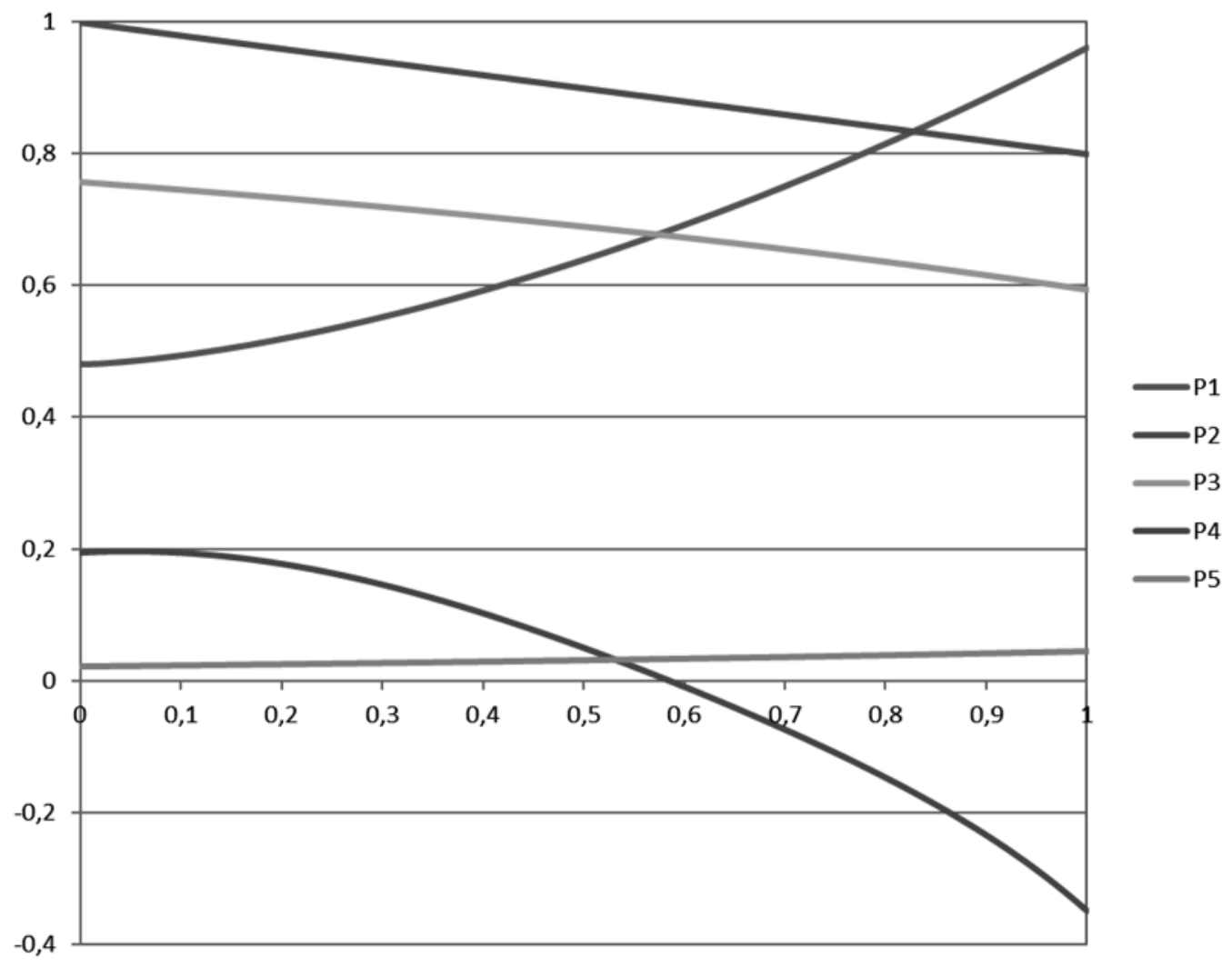

Fig.7. Dependence of the total return level on time

Source: Designed by the authors

The analysis of modeling results undeniably indicates that the most effective scenario is the intensive promotion; certain growth and security of the enterprise's development are provided by the resource-based scenario, while the scenarios of concentrated development, cautious sensing and blind enrichment give a clearly negative result, because almost do not use intangible reserves.

\section{Conclusions}

It has been established that temporal mathematical model of the intensification of using non-material reserves in order to increase the competitiveness of the enterprise, taking into account the level of remuneration indices of the perception of motivational incentives, the perception of enterprise employees of management features, the dynamics of changes in global and local social values, and different scenarios of using intangible reserves can quantitatively determine the effect of using these reserves according to the chosen scenario of development 
and security of enterprise's functioning. Using calculations conducted using the model, it has been determined that the most effective scenario is an intensive promotion scenario based on using positive trends in changing public values in order to ensure maximum perceptions of the most effective management styles. The resourcebased resource scenario has a certain potential of ensuring the competitiveness of the enterprise. Scenarios of cautious sensing and blind enrichment are negative in terms of ensuring the competitiveness of the enterprise, because these scenarios do not use intangible internal reserves.

\section{References}

Aghina, W., De Smet, A. and Heywood, S. (2014). The past and future of global organisaitons, McKinsey Quarterly, 2014 Available at: http://www.mckinsey.com/insights/organisation/the_past_and_future_of_global_organisations

Bartol, Tein and et al, (2003). Management: A Pacific Rim Focus, McGraw-Hill Australia Pty Limited, Australia.

Bombiak, E. 2019. Green human resource management - the latest trend or strategic necessity? Entrepreneurship and Sustainability Issues 6(4): 1647-1662. http://doi.org/10.9770/jesi.2019.6.4(7)

Bushe, G.R. and Marshak, R.J. (2009). Revisioning organization development, diagnostic and dialogic premises and pattems of practice, The Journal of Applied Behavioral Science, 45(3), 1-21. https://doi.org/10.1177\%2F0021886309335070

Cameron, K.S., Quinn, R.E. (2011). Diagnosing and changing organisational culture: Based on the competing values framework. San Francisco: A Wiley Imprint. URL: https://pdfs.semanticscholar.org/9095/28bece85d540beb496170045c1bec74ab8b6.pdf

Cao, G. and McHugh, M. (2005). A Systematic View of Change Management and its Conceptual underpinnings, Systemic Practice and Action Research, October 2005, Volume 18, Issue 5, pp 475-502. https://doi.org/10.1007/s11213-005-8484-4

Cummins, T.G. and Worley, C.G. (2005). Organization Development and Change, South Western, Mason, OH. URL: http://www.mcs. gov.kh/wp-content/uploads/2017/07/Organization-Development-and-Change.pdf

David, F. \& David, F. R. (2016). Strategic Management: A Competitive Advantage Approach, Concepts and Cases. Florence: South Carolina: Francis Marion University

Drobyazko S. (2017). Formation of competitive positions as providing of economic security of insurance companies // International scientific journal “Internauka”. Series: “Economic Sciences”, №2. https://doi.org/10.25313/2520-2294-2017-2-4784

Drobyazko S., Hryhoruk I., Pavlova H., Volchanska V., Sergiychuk S. (2019). Entrepreneurship innovation model for telecommunications enterprises. Journal of Entrepreneurship Education, 22, 2 URL: https://www.abacademies.org/articles/entrepreneurship-innovation-model-for-telecommunications-enterprises-8097.html

Hamel, G. and Zanini, M. (2014). Build a change platform, not a change programme. McKinsey \& Company. URL: http://www.mckinsey.com/insights/organization/build_a_change_platform_not_a_change_program

Hasanudin, A.I., Yuliansyah, Y., Said, J., Susilowati, Ch., Muafi. (2019). Management control system, corporate social responsibility, and firm performance. Entrepreneurship and Sustainability Issues, 6(3), 1154-1168. http://doi.org/10.9770/jesi.2019.6.3(21)

Jankelová, N., Jankurová, A., Beňová, M., Skorková, Z. (2018). Security of the business organizations as a result of the economic crisis. Entrepreneurship and Sustainability Issues, 5(3), 659-671. https://doi.org/10.9770/jesi.2018.5.3(18)

Kabát, L., Filip, S., Filipová, L. (2017). Safety Measurmment Peculiarities in Selected Countries. Journal of Security and Sustainability Issues, 6(3), 343-356. https://doi.org/10.9770/jssi.2017.6.3(2)

Ključnikov, A., Mura, L., Sklenár, D. (2019). Information security management in SMEs: factors of success. Entrepreneurship and Sustainability Issues, 6(4), 2081-2094. http://doi.org/10.9770/jesi.2019.6.4(37)

Korauš, A., \& Kelemen P. (2018). Protection of persons and property in terms of cybersecurity in Economic, Political and Legal Issues of International Relations 2018. Faculty of International Relations of University of Economics in Bratislava, 1-2. Juni 2018, Virt, Editor: EKONÓM, 2018, ISBN 978-80-225-4506-8/ISSN 2585-9404

Korsakienè, R., Liučvaitienè, A., Bužavaitè, M., Šimelytè, A. (2017). Intellectual capital as a driving force of internationalization: A case of Lithuanian SMEs. Entrepreneurship and Sustainability Issues, 4(4), 502-515. https://doi.org/10.9770/jesi.2017.4.4(8)

Koval, V., Duginets, G., Plekhanova, O., Antonov, A., Petrova, M. 2019. On the supranational and national level of global value chain management. Entrepreneurship and Sustainability Issues, 6(4), 1922-1937. http://doi.org/10.9770/jesi.2019.6.4(27) 
Kubeš, V., Rančák, J. (2018). Sustainability of organization return via management techniques. Entrepreneurship and Sustainability Issues, 5(4), 1031-1042. https://doi.org/10.9770/jesi.2018.5.4(23)

Limba, T., Šidlauskas, A. (2018). Secure personal data administration in the social networks: the case of voluntary sharing of personal data on the Facebook. Entrepreneurship and Sustainability Issues, 5(3), 528-541. https://doi.org/10.9770/jesi.2018.5.3(9)

Makedon V., Hetman O., Yemchuk L., Paranytsia N., Petrovska S. (2019a). Human resource management for secure and sustainable development. Journal of security and sustainability issues, 8(3), 345-354. http://doi.org/10.9770/jssi.2019.8.3(5)

Makedon, V., Korneyev, M. (2014b). Improving methodology of estimating value of financial sector entities dealing in mergers and acquisitions. Investment Management and Financial Innovations, 11(1), 44-55.

Marshak, R.J. and Grant, D. (2008). Organizational discourse and new organization development practices, British Journal of Management, 19(S7), 8-19. https://doi.org/10.1111/j.1467-8551.2008.00567.x

Mason, R. (2007). The external environment's effect on management and strategy. A complexity theory approach. Management Decision, 45(1). Available at: www.emeraldinsight.com/doi/abs/10.1108/00251740710718935

Mathis, R. L. (2011). Human resource management. New York: South-Western Cengage Learning Publishing

Matthews, M. (2015). Using Signal Processing Diagnostics to Improve Public Sector Evaluations. Chapter 2 in G. Carey, K. Landvogt and J. Barraket (eds). Designing and implementing public policy: cross-sectoral debates. Routledge. https://doi.org/10.1002/app5.110

Monni, S., Palumbo, F., Tvaronavičienè, M. (2017). Cluster performance: an attempt to evaluate the Lithuanian case, Entrepreneurship and Sustainability Issues 5(1): 43-57. https://doi.org/10.9770/jesi.2017.5.1(4)

Načisčionis, J.; Skrastiņa, U.; Tumalavičius, V. (2018). Secure development of public administration, Sustainability Issues, Journal of Security and Sustainability Issues 8(1): 87-102. https://doi.org/10.9770/jssi.2018.8.1(8)

Page, J., Pearson, J., Jurgeit, B. and Kidson, M. (2012). Transforming Whitehall: Leading Major Change in Whitehall Departments. https://doi.org/10.1111/j.1467-923X.2013.12047.x

Smith, M. S., Stokes, P. F. \& Wilson, J. (2014). Exploring the impact of Investors in People: A focus on training and development, job satisfaction and awareness of the Standard. Employee Relations, 36(3), 266-279. https://doi.org/10.1108/ER-09-2012-0064

Srivastva, S., \& Cooperrider, D. L. (1999). Appreciative management and leadership (Revised edition). Euclid, OH: Williams Custom Publishing.

Worley, C, Hitchin, D and Ross, W (1996). Integrated Strategic Change: How organization development builds competitive advantage, Addison-Wesley, Reading MA

Zeman, T., Břeň, J., Urban, R. (2018). Profile of a lone wolf terrorist: a crisis management perspective. Journal of Security and Sustainability Issues, 8(1), 5-18. https://doi.org/10.9770/jssi.2018.8.1(1)

Zhou, J., Wang, Q., Tsai, S. B., Xue, Y., \& Dong, W. (2017). How to evaluate the job satisfaction of development personnel. IEEE Transactions on Systems, Man, and Cybernetics: Systems, 47(11): 2809-2816. URL: https://ieeexplore.ieee.org/abstract/document/7398159

Zucker, L. G. (1987). Institutional theories of organizations. Annual Review of Sociology, 13, 443-464. https://doi.org/10.1146/annurev. so.13.080187.002303 
Nataliia SAVYTSKA, Doctor of Economic Sciences, Professor, Head of the Department of Marketing and Commercial Activities, Kharkiv State University of Food Technology and Trade

ORCID ID: orcid.org/0000-0001-6569-6772

Hanna CHMIL, PhD in Economics, Associate Professor, Kharkiv State University of Food Technology and Trade ORCID ID: orcid.org/0000-0002-3703-9940

Olena HRABYLNIKOVA, Candidate of Juridical Sciences, Associate Professor at the Department of Civil, Labour and Economic Law, Oles Honchar Dnipro National University

ORCID ID: orcid.org/0000-0001-4251-0384

Olena PUSHKINA, Doctor of Law, Full Professor, Head of Law Department in Alfred Nobel University ORCID: ID: orcid.org/0000-0002-4372-8825

Maria VAKULICH, PhD in Economics, Associate Professor, Head of Scientific Department in Alfred Nobel University ORCID ID: orcid.org/0000-0001-6153-3554

Register for an ORCID ID:

https://orcid.org/register

This work is licensed under the Creative Commons Attribution International License (CC BY).

http://creativecommons.org/licenses/by/4.0/ 